9. Тихолоз Н. Невмирущий Лис Микита, або надзвичайні пригоди Рудого Крутихвоста. // Авторський проект Наталі і Богдана Тихолозів. Франко: Наживо. URL: https://frankolive.wordpress.com/2017/05/31 (з екрану 10.12.2019)

10. Франко I. Я. Хто такий Лис Микита і відки родом?. URL: http://malyatko-tv.com.ua/lys_mykyta_bookivan_franko/ (з екрану 01.12.2019)

11. Франко I. Лис Микита: поема. URL: https://www.ukrlib.com.ua/books/printit.php?tid=3419 (з екрану 09.12.2019)

12. Франко Т. І. «Лис Микита»: критичний розбір поеми Івана Франка. Львів: Наукове товариство ім. Шевченка, 1937. 108 с.

13. Хейзинга Й. Нomo Ludens. Человек играющий. Санкт-Петербург: Изд-во Ивана Лимбаха, 2011. 416 с.

\title{
References
}

1. Fox Mykyta Pranks: performance. (n.d.) Official site of Lviv Puppet Theatre. Retrieved from https://lvivpuppet.com/performance/vitivki-lisa-mikiti/ [in Ukrainian].

2. Diderot D. (1966). The Paradox of the Actor. Kyiv: Mysteztvo [in Ukrainian].

3. Holovach, Yu. \& Palchykov, V. (2007). Fox Mykyta and Network of Language. Journal Physychnykh doslidzhen, Vol. 11, 1, 22-33 [in Ukrainian].

4. Fox Mykyta: A Musical Tale. Official site of Lviv Academic Regional Music and Drama Theater after Yuriy Drohobych. Retrieved from http://www.theatre.in.ua/event/lis-mikita-2/ [in Ukrainian].

5. Fox Mykyta: A Musical Tale. (n.d.) Official site of the Volyn Shevchenko Academic Regional Ukrainian Music and Drama Theatre. Retrieved from http://www.teatr.volyn.ua/performance/120 [in Ukrainian].

6. Magas, L. I. (2012). The Use of Subjects in Folklore in the Poems of I. Franko. Visnyk Mariupolskogo Derzhavnogo University. Seria: Philologia, 7. 33-37 [in Ukrainian].

7. Director's manifestations in the Opera «Fox Mykyta» by Ivan Nebesnyi. Official site of Lviv National Opera. Retrieved from https://opera.lviv.ua/shows/prem-yera-lys-mykyta/ [in Ukrainian].

8. Syrotenko, V. (2016). Identification of Features of the Ethological Genre in Ivan Franko's Tale « Fox Mykyta». Professionalism vchytelia: theoretychni ta methodychni aspecty: naukovyi zbirnyk. DVNZ «Donbass State Pedagogical University», 4, 199-208 [in Ukrainian].

9. Tykholoz, N. (2017). The Immortal Fox of Mykyta, or the Extraordinary Adventures of Red Twist Tail. Author's Project of Natalie and Bohdan Tykholozs. Franco: Live. URL: https://frankolive.wordpress.com/2017/05/31 [in Ukrainian].

10. Franko I. Ya. Who is Fox Mykyta and where is it from? Retrieved from http://malyatkotv.com.ua/lys_mykyta_book-ivan_franko/[in Ukrainian].

11. Franko, I. Ya. (n.d.). Fox Mykyta: a poem. Retrieved from https://www.ukrlib.com/books/printit.php?tid=3419 [in Ukrainian].

12. Franko, T. I. (1937). The Fox of Nikita: A Critical Analysis of Ivan Franko's Poem. Lviv: Naukove Tovarystvo im. Shevchenko [in Ukrainian].

13. Huizinga J. (2011). Homo Ludens. Man, who is playing. St. Petersburg: Ivan Limbach Izdatelskyi Dom, 2011 [in Russian].

Стаття надійшла до редакиії 02.10.2019

Прийнято до публікаиії 1.11.2019

УДК 78.01:371.132

\author{
Косінова Олена Миколаївна, \\ кандидат педагогічних наук, \\ заслужена артистка України, доцент \\ kosinova@meta.ua \\ ORCID 0000-0002-2569-8762
}

\section{ПІДГОТОВКА СТУДЕНТІВ ВИЩИХ НАВЧАЛЬНИХ ЗАКЛАДІВ МИСТЕЦТВ ЯК АКТУАЛЬНИЙ НАПРЯМОК ЕСТЕТИЧНОГО ВИХОВАННЯ В ІНФОРМАЦЙНОМУ СУСПІЛЬСТВІ}

Метою роботи с дослідження поняття естетичного виховання студентів ВЗО як цілеспрямованого і планомірного процесу формування естетичних понять, смаків та ідеалів, ставлення до професії, до природи і мистецтва, до суспільства i побуту, до спілкування і взаємовідносин, розвитку творчого компоненту

(C) Косінова O.М., 2019 
професійної діяльності за законами краси та емоційно-чуттєвої чуйності на прекрасне і бридке. Методологія дослідження передбачає комплексний підхід із застосуванням аналітичного, системного методів, компаративного, що дозволяє зрозуміти, що естетичне виховання творчої молоді потребує змістовного наповнення, створення оптимальних умов для естетичного виховання студентів творчих спеціальностей. Наукова новизна роботи полягає в актуалізації естетичного виховання студентської молоді у контексті розвитку інформаційного суспільства та формуванням нових засад підготовки студентів творчих спеціальностей у вишах. Даний процес передбачає набуття студентами естетичних знань і формування в них відповідних переконань, потреб, інтересів, звичок, навичок і вмінь згідно вимог сучасного інформаційного суспільства. Висновки. Створення естетичних умов передбачає бездоганність спільної педагогічної діяльності суб'єктів і об'єктів виховання 3 точки зору вимог естетики. Таким чином, забезпечення навчальноматеріальних, організаційних, морально-психологічних, естетичних і гігієнічних умов закономірно обумовлює ефективність процесу естетичного виховання студентів ВЗО. Отже, в умовах ВЗО формування особистості майбутнього фахівця 3 гармонійно поєднаними професійними, морально-естетичними, психологічними якостями забезпечується цілеспрямованою виховною роботою. Естетичне виховання розглядається як один із важливих напрямів у процесі реалізації завдань вітчизняної вищої школи. Важливу роль у забезпеченні результативності підготовки та естетичного виховання студентів відіграє творче використання відповідного світового досвіду у галузі професійної підготовки творчої молоді.

Ключові слова: естетичне виховання, інформаційне суспільство, творча діяльність, культурна спадщина, естетичний смак, естетичні почуття.

Косинова Елена Николаевна, кандидат педагогических наук, заслуженная артистка Украины, доиент

Подготовка студентов высших учебных заведений искусств как актуальное направление эстетического воспитания в информационном обществе

Целью работы является исследование понятия эстетического воспитания студентов ВЗО как целенаправленного и планомерного процесса формирования эстетических понятий, вкусов и идеалов, отношение к профессии, к природе и искусству, к обществу и быта, к общению и взаимоотношений, развития творческого компонента профессиональной деятельности по законам красоты и эмоционально-чувственной отзывчивости на прекрасное и безобразное. Методология исследования предполагает комплексный подход с применением аналитического, системного методов, компаративного, что позволяет понять, что эстетическое воспитание творческой молодежи требует содержательного наполнения, создание оптимальных условий для эстетического воспитания студентов творческих специальностей. Научная новизна работы заключается в актуализации эстетического воспитания студенческой молодежи в контексте развития информационного общества и формированием новых принципов подготовки студентов творческих специальностей в вузах. Данный процесс предусматривает приобретение студентами эстетических знаний и формирование у них соответствующих убеждений, потребностей, интересов, привычек, навыков и умений в соответствии с требованиями современного информационного общества. Выводы. Создание эстетических условий предполагает безупречность совместной педагогической деятельности субъектов и объектов воспитания с точки зрения требований эстетики. Таким образом, обеспечение учебно-материальных, организационных, морально-психологических, эстетических и гигиенических условий закономерно обусловливает эффективность процесса эстетического воспитания студентов ВЗО. Следовательно, в условиях ВЗО формирования личности будущего специалиста по гармонично соединенными профессиональными, морально-эстетическими, психологическими качествами обеспечивается целенаправленной воспитательной работой. Эстетическое воспитание рассматривается как одно из важных направлений в процессе реализации задач отечественной высшей школы. Важную роль в обеспечении результативности подготовки и эстетического воспитания студентов играет творческое использование соответствующего мирового опыта в области профессиональной подготовки творческой молодежи.

Ключевые слова: эстетическое воспитание, информационное общество, творческая деятельность, культурное наследие, эстетический вкус, эстетические чувства.

Kosinova Olena, Candidate of Pedagogical Sciences, Honored Artist of Ukraine, assistant professor of directing the National Academy of Managerial Staff of Culture and Arts

Aesthetic Education as Actual Training Direction of Arts High School Students in Information Society

The purpose of this work is to study the concept of aesthetic education of students of the WHO as a purposeful and systematic process of formation of aesthetic concepts, tastes and ideals, attitude to the profession, to nature and art, to society and life, to communication and relationships, development of creative component of professional activity under the laws of beauty and emotional and sensual sensitivity to the beautiful and nasty. The research methodology involves a comprehensive approach with the use of analytical, systematic, and comparative methods, which makes it clear that the aesthetic education of creative youth requires a meaningful content, creating optimal conditions for the aesthetic education of students of creative specialties. The scientific novelty of the work is to actualize the aesthetic education of student youth in the context of the development of the information society and to form new bases for the preparation of students of creative specialties in higher education. This process involves the acquisition of aesthetic knowledge by students and the formation of relevant beliefs, needs, interests, habits, skills and 
abilities according to the requirements of the modern information society. Conclusions. Creating aesthetic conditions implies that the joint pedagogical activity of subjects and objects of education is perfect in terms of the requirements of aesthetics. Thus, the provision of educational, material, organizational, moral and psychological, aesthetic and hygienic conditions naturally determines the effectiveness of the process of aesthetic education of students of the WHO. Thus, in the conditions of WHO the formation of the personality of the future specialist with harmoniously combined professional, moral and aesthetic, psychological qualities is ensured by purposeful educational work. Aesthetic education is considered as one of the important directions in the process of realization of the tasks of the national higher school. An important role in ensuring the effectiveness of the preparation and aesthetic education of students is played by the creative use of relevant world experience in the field of vocational training of creative youth.

Keywords: aesthetic education, information society, creative activity, cultural heritage, aesthetic taste, aesthetic feelings.

Актуальність теми дослідження. Виховання - одна із головних функцій держави. Науковою основою виховного процесу є теорія та методика виховання. Теорія обгрунтовує концепції, принципи, закономірності і мету виховання. Методика розкриває завдання, зміст, методи, засоби, прийоми і форми виховання.

Аналіз досліджень і публікацій. Суттєвий вклад у розкриття сутності виховання зробили А.Луначарський, А.Макаренко, В.Сухомлинський та ін. А.Луначарський у характеристиці сутності виховання величезну увагу приділяв власній активності особистості в опануванні моральністю: “...необхідно розвинути в людині громадянина, необхідно розвинути таку особистість, яка вміє існувати в гармонії із іншими, ... котра пов'язана з іншими співчуттям і думкою соціально [6]”. В.Сухомлинський, розроблюючи теорію виховання, обгрунтував необхідність цілісного підходу до всебічного розвитку особистості. Він підкреслював: “Виховання у широкому розумінні - це багатогранний процес постійного духовного збагачення і оновлення - і тих, хто виховується, і тих, хто виховує. До того ж, цей процес характерний глибокою індивідуалізацією явищ [9]”.

Метою роботи є дослідження поняття естетичного виховання студентів В3О як цілеспрямованого і планомірного процесу формування естетичних понять, смаків та ідеалів, ставлення до професії, до природи і мистецтва, до суспільства і побуту, до спілкування і взаємовідносин, розвитку творчого компоненту професійної діяльності за законами краси та емоційно-чуттєвої чуйності на прекрасне i бридке.

Виклад основного матеріалу. Структура виховного процесу передбачає наявність чітко визначених виховних цілей. В умовах ВЗО виховний процес спрямований на: формування цілісної особистості майбутнього фахівця - спеціаліста визначеного профілю; патріотичне і творче виховання студента - справжнього громадянина Батьківщини; формування високих моральних якостей; гармонійність розвитку інтелектуальної, почуттєвої, вольової і фізичної сфер особистості; естетичне виховання і розвиток здібностей щодо естетично-художньої творчості; мотивацію самовиховання i формування готовності виховувати учнів тощо. Сучасна педагогіка визначає наступні види виховання: патріотичне; правове; моральне; трудове, естетичне, фізичне; формування наукового світогляду та ін. Всі означені складові частини виховання мають особливості. Головна особливість естетичного виховання вплив на почуттєву сферу особистості. Водночас, види виховання перебувають у постійній і тісній єдності; кожен з них має естетичний аспект.

Естетичне виховання студентів В3О є цілеспрямованим і планомірним процесом формування естетичних понять, смаків та ідеалів, ставлення до професії, до природи і мистецтва, до суспільства i побуту, до спілкування і взаємовідносин, розвитку творчого компоненту професійної діяльності за законами краси та емоційно-чуттєвої чуйності на прекрасне і бридке.. Естетичне виховання студентів ВЗО спрямоване на формування у майбутніх фахівців розуміння прекрасного, на розвиток творчих здібностей, потреби, навичок і вмінь зберігати і вносити прекрасне, красиве, піднесене, героїчне в життя, до спілкування і взаємовідносин, розвитку творчого компоненту професійної діяльності за законами краси та емоційно-чуттєвої чуйності на прекрасне і бридке. Цілеспрямований процес естетичного виховання передбачає набуття студентами естетичних знань і формування в них відповідних переконань, потреб, інтересів, звичок, навичок і вмінь. Особливістю естетичного виховання є безпосередній вплив на почуттєву і розумову сфери людини як предметів і явищ середовища, так і творів літератури і мистецтва.

Естетичне виховання формує у студентів розуміння прекрасного, естетичні смаки і високі естетичні ідеали, розвиває потребу зберігати прекрасне і утверджує прагнення вносити прекрасне в життя, будувати його, як підкреслював К.Маркс, “також і за законами краси [3]”. Естетичне виховання дозволяє сформувати у студентів уміння бачити вищий ідеал прекрасного в служінні Батьківщині. Принципи виховання $є$ керівними педагогічними положеннями i відбивають вимоги законів i закономірностей виховного процесу. Найбільш загальною закономірністю естетичного виховання $\epsilon$ 
закономірна залежність педагогічного процесу від вимог сучасного інформаційного суспільства.

Підготовка фахівців в мистецьких ВЗО закономірно залежить від політики та ідеології керівництва держави. Естетичне виховання в інформаційному суспільстві закономірно залежить від сукупності об’єктивних і суб'єктивних факторів середовища, які стимулюють чи гальмують розвиток особистості. Єдність і взаємозв'язок виховання і розвитку особистості - закономірність процесу естетичного виховання. Зв'язок закономірностей (законів) і принципів є складним. Конкретний принцип може відбивати вимоги одного закону, якої-то сторони закону або вимог взаємодії декількох законів. Сукупність принципів визначає спрямованість, зміст, організацію і методику виховного процесу в ВЗО. Розуміння сутності принципів дозволяє свідомо і творчо вирішувати завдання виховання, упорядковувати педагогічну діяльність, обгрунтовано здійснювати іiі і впевнено досягати мети виховання. Систему основних принципів виховання студентів складають: доцільність і зв'язок з життям; виховання у процесі творчої діяльності, навчання і позанавчальної роботи; виховання у колективі і через колектив; індивідуально-диференційований підхід до вихованців; поєднання розумної вимогливості до особистості студентів з повагою до нього; спирання на позитивне в особистості і в колективі; єдність, і спадкоємність педагогічних впливів. Принципи дозволяють проводити виховну діяльність комплексно, злагоджено і уміло. Як початкові педагогічні положення, вони регулюють процес використання засобів, методів, прийомів і форм роботи і сприяють виконанню завдань естетичного виховання студентів ВЗО.

Основними завданнями естетичного виховання студентів ВЗО $є$ : мистецтві;

* формування у студентів правільного розуміння прекрасного у житті, навчанні, у літературі і

* розвиток у вихованців вмінь правильно сприймати прекрасне і бридке, піднесене і низьке, героїчне і непристойне, комічне і трагічне, гармонію, симетрію, пропорцію, ритм, темп, міру у явищах дійсності та мистецтва;

* формування потреби постійного спілкування з прекрасним; виховання нетерпимого ставлення до бридкого у будь-яких його виявах, розвиток навичок керувати своїми почуттями;

* розвиток естетичних смаків студентів, формування в них гідного естетичного ідеалу та вміння бачити красу творчості;

* удосконалення художньої грамотності, ознайомлення з національною і світовою культурною спадщиною, $з$ сучасним мистецтвом; формування потреби художнього саморозвитку; формування потреби, навичок і вмінь естетично-художньої творчості; забезпечення методичної і теоретичної готовності випускників ВЗО проводити естетичне виховання підлеглих у подальшій роботі та ін.

Основні положення естетики виступають фундаментом розробки стратегії і тактики естетичного виховання студентів. Естетика розкриває природу естетичного в житті і мистецтві, вивчає основні принципи естетичного освоєння світу, досліджує закони естетичної діяльності особистості. Прекрасне i бридке, піднесене і низьке, героїчне і непристойне, комічне і трагічне - ці властивості реальних предметів, явищ і ситуацій сприймаються через естетичні почугтя. Естетичні почуття виявляються у відповідних оцінках, смаках, поглядах. Разом з естетичними ідеями і ідеалами вони виступають суб'єктивною стороною естетичного освоєння світу і складають естетичну свідомість людини. Вона є суб'єктивним відбиттям об'єктивного світу і разом з тим виступає знаряддям пізнання суттєвої сторони реального світу - його краси. Розкриваючи структуру і функції естетичної свідомості, естетика визначає процес формування естетичних почуттів, оцінок, смаків, ідеалів. Естетичний смак пов'язаний зі сприйняттям предмету, явища чи твору мистецтва в їх цілості. Сприйняття і оцінка при цьому виступають в єдності. Оцінка визначається естетичними орієнтаціями особистості. Естетичний смак надає можливості більш тонко, диференційовано і об'єктивно оцінити естетичну вартість явища або предмета. Естетичний смак характеризують почуття міри, гнучкість і стійкість оцінок, широта сприйняття. Естетичний смак розвивається, удосконалюється, тобто він залежить від всього комплексу знань і усіх факторів розвитку особистості. Збочення смаку виявляються частіше всього у двох формах: міщанстві й естетстві (снобізмі). Розвинений смак $є$ завжди чуйним і вимогливим до гармонії форми і змісту і явищі чи предметі. Висновком всієї роботи має бути формування естетичного ідеалу. Естетичний ідеал $є$ найбільш загальне уявлення про прекрасне (вищу ступінь досконалості) у природі, суспільстві і людині, яке сприймається як мета. Таким чином, естетична свідомість виступає у вигляді двох основних структурних компонентів: естетичного ідеалу, який висловлює сутність світоглядної сфери свідомості, і естетичного смаку, який $\epsilon$ ядром розумово- емоційної сфери естетичної свідомості. В рамках педагогічного процесу ВЗО відбувається взаємодія між вихователями - суб'єктами естетичного виховання і вихованцями - об'єктами виховання. Педагогічними суб'єктами є викладачі, керівники закладу освіти, працівники соціальнокультурної сфери, діячі мистецтв тощо. 3 позицій суб'єкт-суб’єктного підходу, специфічним для об’єкта виховання - студента - $є$ одночасна наявність у нього властивостей суб'єкта виховання. Педагогічний 
процес характеризується наявністю наступних взаємопов'язаних сторін: формуванням естетичної свідомості, розвитком потреби та вміння будувати своє життя за законами краси, утвердженням ідеалів краси в труді, побуті, в природі, житті. Важливі завдання естетичного виховання в умовах вищої школи формування у студентів естетично-художніх смаків, гідного естетичного ідеалу і виховання культури почуттів.

В педагогічному процесі застосовується комплекс засобів, методів, прийомів і форм роботи. Ефективність педагогічного процесу закономірно залежить від умов, в яких він протікає. До соціальнопедагогічних умов відносяться: організаційні, навчально-матеріальні, морально-психологічні, естетичні, гігієнічні та ін.

Важлива особливість естетичного виховання полягає в тому, що воно може здійснюватись як через вплив на особистість естетичних властивостей предметів і явищ навколишнього середовища, так $\mathrm{i}$ за допомогою літератури та мистецтва. Основними засобами естетичного виховання студентів $є$ : навчання, процес пізнання, праця, побут, спілкування, творчість, література і мистецтво. Естетичні почуття студентів викликають такі елементи учбової діяльності, як гармонія, симетрія, пропорція, ритм, темп. Учбова діяльність і праця активно впливають на естетичний розвиток студентів наступними шляхами: власно процесом діяльності; змістом роботи; стосунками у навчанні; результатами діяльності. Навчально-пізнавальний процес має істотні можливості для естетичного виховання студентів. Проникаючи думкою у сутність предметів, процесів і явищ, які пізнаються, вихованець одночасно сприймає властиві їм естетичні якості. К.Ушинський писав: "У будь-якої науці є більш-менш естетичний елемент, передачу якого учням повинен мати на увазі наставник [3]".

Естетико-виховні можливості побуту є вельми багатими. А.Макаренко підкреслював, що в справі виховання естетика костюму, кімнати, сходів має не менше значення, ніж естетика поведінки [8]. Спілкування також посідає важливу роль в процесі естетичного розвитку особистості. Засобами спілкування є: слово (усне і друковане), міміка, жести, практичні дії. Основним засобом спілкування студентів є слово. Культура мовлення передбачає ії змістовність, образність, яскравість, чистоту, чітку дикцію, плавність, лагідність, ритм.

Природа є багатим джерелом естетичних переживань. У кожен момент навколишня природа має щось прекрасне, що облагороджує почугтя, впливає на увесь духовний стан особистості. Героїчне, піднесене, комічне, трагічне та інші грані суспільного життя обумовлюють ії роль важливого засобу естетичного виховання студентів. Література і мистецтво - надійні і незамінні засоби естетичного виховання. Для формування гармонійно розвиненої особистості студента кожен вид мистецтва має своє специфічне значення. Естетична насолода при сприйнятті творів мистецтва виникає як результат причетності до творчості митців. Величезний вплив на духовний світ студентів справляє література. Слово як засіб літературно-художньої творчості здатне створювати яскраві образи і аналізувати явища життя. Прекрасне у житті та навчанні - і засіб, і результат естетичного виховання. Практика доводить, що вирішальним фактором естетичного розвитку студентів $\epsilon$ не засоби самі по собі, а творче ставлення студентів до них. Активне ставлення формується внаслідок ефективної педагогічної діяльності. Педагогічна діяльність з естетичного виховання студентів ВЗО включає: навчально-виховний процес і організацію навчання; позанавчальну діяльність і організацію дозвілля; самодіяльну естетико-художню творчість. Кожен з означених елементів педагогічної діяльності передбачає використання відповідних методів, прийомів і форм роботи.

Метод виховання - це сукупність засобів і прийомів однорідних за своєю педагогічною функцією впливів на психіку і поведінку вихованців. Означені впливи здійснюються у відповідності з завданнями виховання, здібностями особистості і урахуванням конкретної ситуації. Виховання забезпечується системою методів: переконання; прикладу; вправи; змагання; заохочення; критики і самокритики; примусу. Метод переконання - основний метод виховання. Він апелює до розуму, логіки, почуттів $\mathrm{i}$ досвіду людини, забезпечуючи добровільне прийняття ідей, формування переконань і перетворення їх в мотиви поведінки. Метод прикладу $є$ цілеспрямованим і планомірним впливом на свідомість і поведінку студентів системою позитивних прикладів, які закликані бути основою формування ідеалу поведінки, засобом самовиховання. Відрізняються групи прикладів безпосереднього і опосередкованого впливу на свідомість вихованців. Важливе місце у вихованні студентів належить прикладам опосередкованого впливу (через усне слово, літературу, театр, кінофільми, образотворче мистецтво тощо). До них відносяться: приклади життя і діяльності історичних особистостей; видатні приклади індивідуального і масового героїзму у захисті Батьківщини; приклади трудового героїзму сучасників в усіх галузях діяльності та ін. Метод вправи передбачає накопичення студентами естетичного досвіду, формування в них позитивних естетичних якостей, звичок, потреб і інтересів, розвиток педагогічної майстерності. Використання методу змагання дозволяє розвинути у студентів дух здорового суперництва і рівняння на 
кращих, стимулювати співпрацю і взаємодопомогу у колективі. До основних принципів змагання відносяться: гласність; порівнянність результатів; створення умов для розповсюдження кращого досвіду. Метод заохочення складає систему засобів і прийомів морального і матеріального стимулювання високих результатів естетичного виховання студентів. Сутність методу критики i самокритики полягає в використанні системи впливів на студентів 3 метою виховання у них високого почуття відповідальності за своєчасне i якісне виконання завдань естетичного виховання. Жоден 3 названих методів не $\epsilon$ універсальним. Виконання усієї сукупності завдань естетичного виховання студентів досягається творчим використанням всього арсеналу методів у процесі взаємодії суб'єкта і об'єкта виховання. Прийоми виховного впливу добираються у відповідності з функцією методу та тими властивостями людини, що обумовили вибір означеного методу. Зокрема, для переконання студентів використовуються таки прийоми: порівняння, зіставлення, протиставлення, аналогія, синтез, узагальнення. “Факти, якщо узяти їх у цілому, в їх зв’язку, є не лише “затята”, а й безумовно доказова річ. Фактики, якщо вони беруться поза цілим, поза зв’язком, якщо вони уривчасті, ...є саме лише іграшкою [12]”.

Форми проведення естетичного виховання студентів закономірно обумовлені його завданнями, змістом, обраними засобами, методами і прийомами виховання. В рамках кожного елементу педагогічної діяльності з естетичного виховання студентів використовуються специфічні форми роботи. Навчальновиховний процес В3О активно стимулює естетичний розвиток особистості. Кожен навчальний предмет має значні можливості для естетичного виховання студентів Усі форми навчальної діяльності: лекції, семінари, практичні заняття, тренування, практичні заняття характеризуються певним рівнем естетичного навантаження. Зокрема, індивідуальні заняття не лише дають знання, формують творче мислення i розвивають навички творчої діяльності. Студенти привчаються бачити красу узгоджених дій, збагнути естетичні начала у спільній колективній діяльності. Заняття з ритміки, пластики виховують у студентів стрункість, акуратність і зібраність, привчають їх до чітких, узгоджених і красивих дій. На заняттях 3 суспільних наук викладач має можливість показати красу піднесеного і героїчного і довести нікчемність непристойного, бридкого. Важливу роль у естетичному вихованні майбутніх спеціалістів відіграє вивчення спеціальних культурологічних дисциплін: естетики, етики, культурології, рідної і іноземної мов, сценічної мови, акторської майстерності, а також основ загальної психології. Студенти беруть участь у різних формах організації побуту: підтримують чистоту і порядок у гуртожитках та на території академії тощо. При проведенні позанавчальної роботи з студентами важливе місце посідають різноманітні форми сприйняття творів мистецтва. Проводяться покази 3 акторської майстерності, сценічної мови, режисури, зустрічі з видатними діячами літератури і мистецтва, відвідування художніх галерей, виставок, музеїв, історичних пам'яток, театральних вистав, кінотеатрів, концертів тощо.

В умовах ВЗО активно використовуються форми естетично-художньої творчості у заходах за інтересами, у звукостудіях тощо. Означена робота сприяє опануванню кожним студентом навичками i вміннями творити прекрасне у житті і мистецтві. Логіка виховного процесу вимагає його повної доцільності i запобігання будь-яких шаблонів. А.Макаренко підкреслював, що “немає ніяких непогрішимих засобів, і немає засобів обов'язково хибних. В залежності від обставин, часу, властивостей особистості та колективу, від таланту та підготовки виконавців, від найближчої мети, від щойно вичерпаної кон'юктури діапазон використання того чи іншого засобу може сягати ступеня повної спільності або зменшуватися до стану повного заперечення [8]". Вдало поставлене естетичне виховання студентів спрямовує і спонукає їх до естетичного самовиховання і керує означеним процесом. Естетичне самовиховання студентів є важливою складовою частиною педагогічного процесу. Процес естетичного самовиховання грунтується на сформованих раніше інтересах і потребах до естетичного у житті i мистецтві, на накопиченому досвіді естетично-художньої творчості. Методами і засобами естетичного самовиховання виступають методи i засоби естетичного виховання. Педагогічне керівництво здійснюється поетапно. Студенту допомагають скласти самохарактеристику; визначається програма естетичного самовиховання; організується практична діяльність і поточний самоконтроль. Естетичне самовиховання сприяє виконанню завдань естетичного виховання, зокрема формуванню у майбутніх спеціалістів готовності проводити естетичне виховання своїх учнів.

Висновки. Результативність педагогічного виховання студентів В3О закономірно залежить від умов, у яких він здійснюється. До умов відносяться: природно-географічні, правові, економічні, морально-психологічні, наукові, культурні, навчально-матеріальні, організаційні, естетичні, гігієнічні та iн. Керівні і нормативні документи визначають роль керівництва В3О, професорсько-викладацького складу, складу виховної роботи і відділу забезпечення навчального процесу у створенні необхідних умов здійснення педагогічного процесу. Передбачається забезпечення студентів підручниками, навчальними посібниками, учбовими кінофільмами, музичними інструментами тощо. Чітка організація навчання, висока дисципліна і порядок у В3О є необхідними умовами результативності педагогічного процесу. 
Першорядне місце посідають відбір студентів на навчання, чітка організація навчально- виховного процесу і порядок розподілу на практику. Зберігання традицій навчального закладу доповнюється яскравими ритуалами посвяти у студенти, випуску молодих спеціалістів тощо. Дисциплінованість, відповідальність і почуття обов'язку у студентів підвищуються, коли вони осягають не тільки регламентуючу роль порядку, але і його естетичну привабливість. Створення естетичних умов передбачає бездоганність спільної педагогічної діяльності суб'єктів і об'єктів виховання з точки зору вимог естетики. Таким чином, забезпечення навчально-матеріальних, організаційних, моральнопсихологічних, естетичних і гігієнічних умов закономірно обумовлює ефективність процесу естетичного виховання студентів ВЗО. Отже, в умовах ВЗО формування особистості майбутнього фахівця 3 гармонійно поєднаними професійними, морально-естетичними, психологічними якостями забезпечується цілеспрямованою виховною роботою. Естетичне виховання розглядається як один із важливих напрямів у процесі реалізації завдань вітчизняної вищої школи. Важливу роль у забезпеченні результативності підготовки та естетичного виховання студентів відіграє творче використання відповідного світового досвіду у галузі професійної підготовки творчої молоді.

\section{Jimepamypa}

1. Абашкіна Н.В. Нові концепції навчання і виховання у сучасній німецькій педагогіці. К.: Інститут системних досліджень освіти, 1995. 32 с.

2. Библер В.С. Школа диалога культур // Искусство в школе. М., 1992. №2. С.48.

3. Відродження i розвиток культури України: проблеми історії, теорії і практики // Тези доповідей Всеукраїнської наукової конференції. К.: Друкар. 1993. 170 с.

4. Гончаренко С. Не руйнувати, а реформувати // Товариш. 1997. №25. С.3.

5. Кант И. Критика способности суждения. М.: Искусство, 1994. 367 с.

6. Косів М. Про духовне плебейство і не тільки // Культура і життя. 1995. № 27.

7. Луначарский А.В. Избранные статьи по эстетике. М. : Искусство, 1975. 391 с.

8. Макаренко А.С. О воспитании. М.: Политиздат, 1988. С.27.

9. Маслов В.С. Теорія та практика культурологічного виховання / В.С. Маслов. К. : КВГІ, 1995. С.11-76.

10. Національна державна комплексна програма естетичного виховання. Проект / АПН України, Інститут українознавства КДУ ім.Т.Шевченка ; Уклад. І.І. Зязюн, О.М. Семашко. К., 1994. С.23.

11. Педагогічні технології: Навчальний посібник для вузів / О.Падалка, А.Нісімчук, І.Смолюк та ін. ; Укр. пед.ун-т ім. М.Драгоманова. К.: Українська енциклопедія, 1995. 254 с.

12. Men Near TV // Washington Post. 1995. 18.07. P.3.

\section{References}

1. Abashkina N.V. (1995). Novi kontseptsii navchannia i vykhovannia u suchasnii nimetskii pedahohitsi. K.: Instytut systemnykh doslidzhen osvity [in Ukrainian].

2. Bibler V.S. (1992). Shkola dialoga kul'tur. Iskusstvo v shkole. M. №2. S.48 [in Russian].

3. Vidrodzhennia i rozvytok kultury Ukrainy: problemy istorii, teorii i praktyky (1993)Tezy dopovidei Vseukrainskoi naukovoi konferentsii. K.: Drukar [in Ukrainian].

4. Honcharenko S. (1997). Ne ruinuvaty, a reformuvaty. Tovarysh. № 25. S.3. [in Ukrainian].

5. Kant I. (1994). Kritika sposobnosti suzhdeniia. M.: Iskusstvo, [in Russian].

6. Kosiv M. (1995). Pro dukhovne plebeistvo i ne tilky. Kultura i zhyttia. № 27 [in Ukrainian].

7. Lunacharskii A.V. (1975). Izbrannye stat'i po estetike / A.V. Lunacharskii; sost. A.Ermakova. M. : Iskusstvo [in Russian].

8. Makarenko, A.S. (1988). O vospitanii. M.: Politizdat. S.27 [in Russian].

9. Maslov, V.S. (1995). Teoriia ta praktyka kulturolohichnoho vykhovannia. K. : KVHI, S.11-76 [in Ukrainian].

10. Natsionalna derzhavna kompleksna prohrama estetychnoho vykhovannia. Proekt. (1994). K. [in Ukrainian].

11. Pedahohichni tekhnolohii: Navchalnyi posibnyk dlia vuziv (1995) / O.Padalka, A.Nisimchuk, I.Smoliuk ta in. ; Ukr. ped.un-t im. M.Drahomanova. K.: Ukrainska entsyklopediia [in Ukrainian].

12. Men Near TV. Washington Post. 1995. 18.07. P.3 [in Ukrainian]. 